\title{
GASTRIC CRYPTOSPORIDIOSIS AS A CLUE FOR THE DIAGNOSIS OF THE ACQUIRED IMMUNODEFICIENCY SYNDROME
}

\author{
Cyntia Mendes CLEMENTE*, Carlos Antonio CARAMORI**, \\ Pedro PADULA** and Maria Aparecida Marchesan RODRIGUES***
}

\begin{abstract}
Cryptosporidium parvum has been detected with increasing frequency in the gastrointestinal tract, but involvement of the stomach is rarely reported. Whenever found in the histologic examination of the gastrointestinal mucosa, it should raise the suspicion of an immunocompromised host. We report a case of Cryptosporidium-associated erosive gastritis in a 64-year-old woman, who was found later to have the acquired immunodeficiency syndrome. Gastroduodenoendoscopy and biopsy of the gastric mucosa played an invaluable role in the diagnosis of cryptosporidiosis and to disclose the underlying immunodeficiency state.
\end{abstract}

HEADINGS - Cryptosporidiosis. Gastritis. Acquired immunodeficiency syndrome. AIDS-related opportunistic infections.

\section{INTRODUCTION}

Cryptosporidium parvum is a common protozoan that has been found as an emerging infectious threat, especially in immunocompromised hosts ${ }^{(14,15,18,22)}$. It can cause acute or chronic, self limited watery diarrhea in immunocompetent hosts, but severe and prolonged diarrhea, often ending in death in AIDS patients ${ }^{(8,9,11)}$. The ileal mucosa is the center of cryptosporidium colonization ${ }^{(18,22)}$ but it may spread throughout the gastrointestinal tract, especially in immunocompromised hosts ${ }^{(6,12,15)}$. Involvement of the upper gastrointestinal tract has been detected with increasing frequency ${ }^{(2,5,10,16)}$.
The aim of this paper is to present the clinicopathologic and endoscopic features of a case of Cryptosporidiumassociated erosive gastritis and to highlight the importance of upper endoscopy and biopsy for the diagnosis of opportunistic infections which was in this case the clue for the diagnosis of AIDS.

\section{CASE REPORT}

A 64-year-old white woman was hospitalized for evaluation of watery diarrhea, abdominal pain and $10 \mathrm{~kg}$ weight loss during the preceding one month. Physical examination was remarkable for dried mucous membranes and weight loss.

Carried out at Departments of Pathology and Medicine, Division of Gastroenterology, Faculdade de Medicina de Botucatu - FMB-UNESP, Botucatu, SP, Brazil.

* Medical Resident, Division of Gastroenterology.

** Assistant Professor, Department of Internal Medicine, Division of Gastroenterology.

*** Associate Professor, Department of Pathology.

Address for correspondence: Dr. M. Aparecida Marchesan Rodrigues, Caixa Postal 564 - 18618-000 - Botucatu, SP, Brazil. e-mail: mariar@fmb.unesp.br 

syndrome

Laboratory studies showed normal complete blood counts, electrocytes and liver enzymes. Stool examinations were negative for ova and parasites, cultures were negative for bacteria and fungi. An upper gastrointestinal endoscopy performed at the second day of hospitalization, showed thickened antral folds, with erithematous, friable and granular appearance extending through the pylorus and duodenum. Biopsies were taken from these sites and the histopathological examination revealed an erosive inflammation with many small, basophilic and spheric structures, cryptosporidia, clustered on the surface of the epithelial cells. There was also coinfection with Helicobacter pylori. Special stains for fungi, acid-fast bacilli and viral inclusions were negative. The patient was treated with rovamicina, with partial improvement of the symptoms. Another upper gastrointestinal endoscopy performed two weeks later, still showed the stomach with erythematous and exudative aspect. The duodenum had the same appearance. Cryptosporidia and Helicobacter pylori still were present at the histopathological examination, together with inflammation and regeneration. No further detailed investigation was performed to establish the extent of involvement of other parts of the gastrointestinal tract, since the patient was transferred to another ward. Investigation of the immune status revealed serum anti-HIV antibodies positive by ELISA and antiretroviral agents were introduced. The only risk factor assessed was a prior blood transfusion 10 years ago. The patient died in another city few months later and no post mortem examination was performed.

\section{DISCUSSION}

Cryptosporidium gastropathy was first described in 1984 with cytomegalovirus coinfection ${ }^{(1)}$ and in 1992 as the unique pathogen ${ }^{(4)}$.

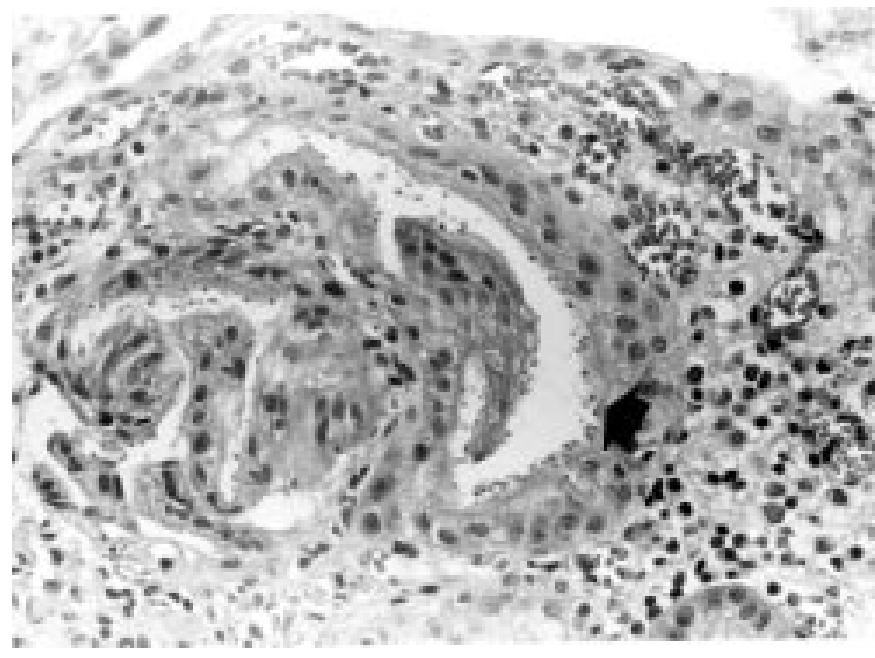

FIGURE 1 - Histology of the gastric mucosa showing inflammation and many small, dark and spheric structures (cryptosporidia) attached to the border of the epithelial cells (arrow) H-E 400x.
In Brazil involvement of the gastric mucosa with Cryptosporidium parvum is seldom reported ${ }^{(7,19)}$. COELHO et al. ${ }^{(7)}$ detected gastric cryptosporidiosis in two out of 60 patients with AIDS systematically submitted to biopsies of the gastric mucosa. Their endoscopic findings were similar to ours, but they did not mention coinfection with Helicobacter pylori.

In an autopsy-based study of 45 cases of AIDS-associated opportunistic infections of the gastrointestinal tract, CARVALHO et al. ${ }^{(3)}$ did not find any case of involvement of the gastric mucosa by cryptosporidium among three cases of intestinal cryptosporidiosis, two at the small bowel, affecting the ileal mucosa and one in the colon.

In the present report the diagnosis of cryptosporidiosis was achieved by endoscopy and biopsy of the gastric mucosa, performed due to upper abdominal pain. Stool analysis failed to demonstrate $C$. parvum, despite the symptomatic diarrhea. In a recent review of the literature on gastric cryptosporidiosis, VENTURA et al. ${ }^{(23)}$ reported that in 14 out of 16 patients, the diagnosis was made based on biopsy of the gastric mucosa, rather than by examination of the stools. Although it has been advised that the detection of cryptosporidium should be performed in fecal tests, without invasive procedures ${ }^{(17)}$, this does not seem to be true in the clinical practice. GREENBERG et al. ${ }^{(12)}$ compared the sensitivity of stool analysis and endoscopic biopsies of the gastrointestinal tract in the diagnosis of cryptosporidiosis in 30 patients with severe diarrhea and AIDS. They have found C. parvum in 53\% of individual stool samples and stressed that stool analysis was not sensitive in the diagnosis of intestinal cryptosporidiosis.

In the present case the histopathologic analysis of the gastric mucosa demonstrated epithelial cell damage and significant acute inflammation. This might be related in part to coinfection with $H$. pylori, which elicits an influx of neutrophils into the mucosa. On the other hand, in vitro studies have indicated that cryptosporidium infection induces an apical defect in the host cell that causes epithelial cell death ${ }^{(13)}$. Histopathological studies of the gastric mucosa associated with the presence of $C$. parvum as the unique pathogen have shown nonspecific inflammation together with epithelial reactive changes ${ }^{(20}$, ${ }^{21)}$. RIVASI et al. ${ }^{(20)}$ demonstrated a close relationship between the intensity of C. parvum infection and the degree of histological alterations. They did not find a clear correlation between the endoscopic and histologic picture.

In conclusion, the histopathologic finding of cryptosporidium infection in the gastric mucosa in our case was the clue for the diagnosis of AIDS, which might be associated with a prior blood transfusion as the unique risk factor in the clinical history of the patient. The upper gastrointestinal endoscopy with biopsy was invaluable for the diagnosis of the opportunistic infection and to disclose the underlying disease. 
Clemente CM, Caramori CA, Padula P, Rodrigues MAM. Criptosporidiose gástrica como pista para o diagnóstico da síndrome da imunodeficiência adquirida. Arq Gastroenterol 2000;37(3):180-182.

RESUMO - Infecções oportunistas do trato gastrointestinal constituem ameaça à população crescente de portadores de imunossupressão. O comprometimento do estômago por Cryptosporidium é incomum. Quando identificado no exame histopatológico da mucosa gástrica, é mandatória a investigação do estado imunológico do hospedeiro. São apresentados os dados clinicopatológicos e endoscópicos de uma paciente de 64 anos com gastrite erosiva associada à infecção por Cryptosporidium. O encontro deste agente oportunista no exame histopatológico da mucosa gástrica foi fundamental para esclarecer a doença de base da paciente, que era a síndrome da imunodeficiência adquirida.

DESCRITORES - Criptosporidiose. Gastrite. Síndrome de imunodeficiência adquirida. Infecções oportunistas relacionadas com a AIDS.

\section{REFERENCES}

1. Berk RN, Wall SD, McArdle CB. Cryptosporidiosis of the stomach and small intestine in patients with AIDS. Am J Radiol 1984;143:549.

2. Besasso HR, Macias J, Trombetta LA, diRisio, Cecilia A, Argento R, Besushio SC. Gastritis erosiva asociada a Criptosporidium en dos pacientes con SIDA. Acta Gastroenterol Latinoam 1994;24:41.

3. Carvalho MGF, Rodrigues MAM, Marques ME, Franco MF, Montenegro MR Lesões do trato gastrointestinal na síndrome da imunodeficiência adquirida: Estudo de 45 necrópsias consecutivas. Rev Soc Bras Med Trop 1994;27:135.

4. Cesosimo E, Wildowske C, Rosenblatt J, Ludwig J. Isolated antral narrowing with gastrointestinal cryptosporidiosis in the acquired immunodeficiency syndrome. Mayo Clin Proc 1992;67:553.

5. Chalasani N, Lazenby AJ, Mel Wilcox C. Unusual endoscopic features of gastric and duodenal cryptosporidiosis in AIDS. Gastrointest Endosc 1997;45:525-7.

6. Clayton F, Heller T, Kotler DP. Variation in the enteric distribution of cryptosporidia in acquired immunodeficiency syndrome. Am J Clin Pathol 1994;102:420.

7. Coelho LK, Castro G, Martinez R, Modena JLP. Cryptosporidiosis in the stomach of patients with acquired immunodeficiency syndrome. Endoscopy 1997;29:S45.

8. Colford JM Jr, Tager IB, Hirozawa AM, Lemp GF, Aragon T, Petersen C. Cryptosporidiosis among patients infected with human immunodeficiency virus. Factors related to symptomatic infection and survival. Clin Infect Dis 1998;27:536.

9. Dupont HL, Chappell CL, Sterling CR, Okhuysen PC, Rose JB, Jadubowski W. The infectivity of Cryptosporidium parvum in healthy volunteers. $\mathrm{N}$ Engl $\mathrm{J}$ Med 1995;332:855.

10. Garone MA, Winston BJ, Lewis JH. Cryptosporidiosis of the stomach. Am J Gastroenterology 1986;81:465.

11. Goodgame RW, Kimball K, Ching N, Ou CN, Clinton White A Jr, Genta RM, Lifschitz $\mathrm{CH}$, Chappell CL. Intestinal function and injury in acquired immunodeficiency syndrome-related cryptosporidiosis. Gastroenterology 1995; 108:1075.

12. Greenberg PD, Koch J, Cello JP. Diagnosis of Cryptosporidium parvum in patients with severe diarrhea and AIDS. Dig Dis Sci 1996;41:2286-90.
13. Griffiths JK, Moore R, Dooley S, Keusch GT, Tzipori S. Cryptosporidium parvum infection of Caco-2 cell monolayers induces an apical monolayer defect, selectively increases transmonolayer permeability and causes epithelial cell death. Infect Immun 1994;62:4506.

14. Guerrant RL. Cryptosporidiosis: an emerging, highly infectious threat. Emerg Infect Dis 1997;3:51.

15. Lumadue JA, Manabe YC, Moore RD, Belitsos PC, Sears CL, Clark DP. A clinicopathologic analysis of AIDS-related cryptosporidiosis. AIDS 1998;12:2459-66.

16. Moon A, Spivak W, Brandt LJ. Cryptosporidium-induced gastric obstruction in a child with congenital HIV infection: case report and review of the literature. J Pediatr Gastroenterol Nutr 1999;28:108-11.

17. Morin CA. What do physicians know about cryptosporidiosis? A survey of Connecticut physicians. Arch Intern Med 1997;157:1017.

18. Navin TR, Juranek DD. Cryptosporidiosis: clinical epidemiologic and parasitologic review. Rev Infect Dis 1984;6:313.

19. Nunez MRZ, Sakai P, Ishioka S, Laudanna AA. Gastroduodenite erosiva associada a Cryptosporidium num paciente com síndrome de imunodeficiência adquirida. Rev Hosp Clin Fac Med São Paulo 1990;45:188-9.

20. Rivasi F, Rossi P, Righi E, Pozio E. Gastric cryptosporidiosis: correlation between intensity of infection and histological alterations. Histopathology 1999;34 405-9.

21. Rossi P, Rivasi F, Codeluppi M, Catania A, Tamburrini A, Righi E, Pozio E. Gastric involvement in AIDS associated cryptosporidiosis. Gut 1998;43:4767.

22. Tzipori S. Cryptosporidiosis in perspective. Adv Parasitol 1988;27:63.

23. Ventura G, Larocca LM, Riccioni ME, Tumbarello M, Lucia MB. Gastric cryptosporidiosis complicating HIV infection: case report and review of the literature. Eur J Gastroenterol Hepatol 1997;9:307. 